https://doi.org/10.31743/sanp.9847

\title{
SPRAWOZDANIE Z WIDEOKONFERENCJI NAUKOWEJ, PT. PAŃSTWA DE FACTO: WEWNĘTRZNa I ZEWNĘTRZNA DYNAMIKA, W DNIU 2 KWIETNIA 2020 R.
}

W dniu 2 kwietnia 2020 r. odbyła się wideokonferencja Państwa de facto: wewnętrzna i zewnętrzna dynamika, zorganizowana przez Katedrę Stosunków Międzynarodowych i Bezpieczeństwa KUL. Główną ideą przedsięwzięcia była prezentacja badań polskich badaczy nad szeroko rozumianymi jednostkami geopolitycznymi mającymi podstawowe atrybuty państwowości, jednak nieuznanymi powszechnie za państwa przez społeczność międzynarodową. Dodatkowo konferencja miała na celu sprzyjać integracji środowiska badaczy państw de facto.

Grupa ośmiorga naukowców, którzy uczestniczyli w wydarzeniu, swoje zainteresowania badawcze koncentruje wokół funkcjonowania jednostek politycznych takich jak: Republika Chińska (Tajwan), Republika Kosowa, Katalonia, Abchazja czy też Kurdystan. Całość konferencja określona została ramami skutków braku uznania $\mathrm{w}$ międzynarodowym prawie publicznym oraz udziałem państw de facto w stosunkach międzynarodowych.

Pierwszemu zagadnieniu poświęcone było wystąpienie dr Agaty Kleczkowskiej z Polskiej Akademii Nauk. Autorka w swoim referacie zwracała uwagę na konsekwencje braku uznania między innymi dla kwestii członkostwa państw de facto $\mathrm{w}$ organizacjach międzynarodowych, w tym pozostawaniu tych jednostek geopolitycznych poza systemem bezpieczeństwa. Z kolei dr hab Marcin Kosienkowski z Katolickiego Uniwersytetu Lubelskiego zaprezentował wystąpienie, które przedstawiało miejsce i rolę państw de facto $\mathrm{w}$ międzynarodowych stosunkach politycznych oraz historię, a także pola współpracy społeczności międzynarodowej z quasi-państwami.

Kolejne referaty stanowiły rodzaj studiów przypadków. Pierwsze dwa autorstwa dr Roberta Rajczyka z Uniwersytetu Śląskiego w Katowicach oraz dr hab. Konrada Pawłowskiego z Uniwersytetu Marii Curie-Skłodowskiej prezentowały kazusy Republiki Chińskiej (Tajwanu) oraz Republiki Kosowa. Oba podmioty polityczne różnią się stopniem uznania międzynarodowego, ale $\mathrm{w}$ porównaniu z pozostałymi para-państwowymi jednostkami geopolitycznymi, cieszą się częściowym uznaniem międzynarodowym 
i w ograniczonym liczbowo zakresie utrzymują regularne stosunki dyplomatyczne z pozostałymi pierwotnymi podmiotami prawa międzynarodowego. W odniesieniu do wtórnych podmiotów prawa międzynarodowego, Kosowo i Tajwan uczestniczą $\mathrm{w}$ różnych formach $\mathrm{w}$ pracach organizacji międzynarodowych, z tym, że Kosowo w przeciwieństwie do Tajwanu, pod własną nazwą. Republika Chińska na ogół bowiem bierze udział w międzynarodowych stosunkach politycznych, kulturalnych i gospodarczych jako Chińskie Tajpej lub też Wydzielony Obszar Celny Tajwanu, Pengu, Kinmen i Matzu.

Problem separatyzmu katalońskiego z kolei był tematem referatu dr Wioletty Husar-Poliszuk z Uniwersytetu Zielonogórskiego. Autorka zaprezentowała jednak także i ujęcie proponowany przez przeciwników niepodległości Katalonii obejmujący obszar o nazwie Tabarnia. Modelom przywództwa politycznego natomiast poświęcone było wystąpienie mgr Agnieszki Tomczyk z Uniwersytetu Warszawskiego, która za podstawę swoich badań przyjęła ewolucję sceny politycznej w Abchazji w ujęciu chronologicznym. Republice Abchazji swój referat dedykował także mgr Tomasz Grzywaczewski, który pochylił się nad problemem promocji Abchazji ze szczególnym uwzględnieniem udziału jej reprezentacji piłkarskiej w mistrzostwach świata państw nieuznawanych.

Ostatnim analizowanym przypadkiem podczas wideokonferencji był status prawnomiędzynarodowy irackiego Kurdystanu. Mgr Piotr Sosnowski z Uniwersytetu Warszawskiego swoją analizę skoncentrował przede wszystkim na problematyce polityki bezpieczeństwa tego organizmu para-państwowego.

Konferencja Państwa de facto: wewnętrzna i zewnętrzna dynamika realizowana była w formie zdalnej 2 kwietnia 2020 roku. Organizatorem wydarzenia był dr hab Marcin Kosienkowski z KUL.

Robert Rajczyk ${ }^{1}$

1 Dr Robert RAJCZYK, Instytut Dziennikarstwa i Komunikacji Medialnej Uniwersytet Śląski w Katowicach, e-mail: robert.rajczyk@us.edu.pl 